\title{
ALLELOPATHIC EFFECT OF Tephrosia cinerea L. (Pers.) PLANT EXTRACTS IN LETTUCE
}

\author{
Ana Yasha Ferreira de La Salles ${ }^{1}$, Jacob Silva Souto ${ }^{2}$, César Henrique Alves Borges ${ }^{3}$, Lyanne dos Santos Alencar ${ }^{4}$,
} Francisco Tibério de Alencar Moreira ${ }^{5}$

\begin{abstract}
Allelopathy has been conceptualized as the direct or indirect effect of a plant onto another one through secondary metabolites, or allelochemicals spread in the environment, with the power to interfere in seed germination and increase or inhibit the development of neighboring plants. The objective of this study was to analyze the possible allelopathic effects of aqueous extracts of Tephrosia cinerea in the germination of lettuce (Lactuca sativa L.) seeds. The experiment has been carried out at the Laboratório de Nutrição Mineral de Plantas (Laboratory of Plant Mineral Nutrition)/UAEF/UFCG in Patos (state of Paraíba). We collected T. cinerea organisms, having separated the stem, leaves, roots fractions and the aerial part of the plant + roots, having prepared the extract at $20 \%$. The experimental delineation that we adopted was entirely casualized, with five treatments and four repetitions (without extract, leaf extract, root extract, stem extract, aerial part extract + roots). The seeding was held in aluminum trays, with autoclaved sand as the substrate, setting 25 seed per tray. The calculation of the number of germinated seeds was made in a dailybasis, and, after a week of seeding, the next step was the deactivation, with the evaluations being performed regarding the length of the radicle and of the hypocotyl, as well as the height of the seedlings. The data collected in this research allows us to conclude that: the extracts obtained from $T$. cinerea plants has a negative impact on the germination of lettuce seedlings. Now, when it comes to the height of lettuce seedlings, it is affected by the use of leaf, stem and aerial part extracts $+T$. cinerea roots. It is crucial to make efforts in order to determine the existing constituents in the several parts of $T$. cinerea plants.
\end{abstract}

Keywords: Allelopathy; Neighboring Plant; Germination

\section{RESUMO}

\section{EFEITO ALELOPÁTICO DE EXTRATO dE PLANTAS DE TEPHROSIA CINEREA L. (PERS.) EM ALFACE (LACTUCA SATIVA L.)}

A alelopatia tem sido conceituada como o efeito direto ou indireto de uma planta sobre outra por meio de metabólitos secundários ou aleloquímicos liberados no ambiente, podendo interferir na germinação de sementes e aumentar ou inibir o desenvolvimento de plantas vizinhas. O objetivo deste trabalho foi estudar os possíveis efeitos alelopáticos de extratos aquosos de Tephrosia cinerea na germinação de sementes de alface (Lactuca sativa L.). O experimento foi conduzido no Laboratório de Nutrição Mineral de Plantas/UAEF/UFCG, em Patos (PB). Indivíduos de T. cinerea foram coletados, separando as frações caule, folhas, raízes e parte aérea + raízes, preparando-se o extrato a $20 \%$. O delineamento experimental utilizado foi inteiramente casualizado, com cinco tratamentos e quatro repetições (sem extrato, extrato de folhas, extrato de raízes, extrato de caule, extrato de parte aérea + raízes). A semeadura foi realizada em bandejas de alumínio tendo como substrato areia autoclavada, dispondo-se 25 sementes por bandeja. A contagem do número de sementes germinadas foi realizada diariamente e, após sete dias da semeadura, seguiu-se a desativação, sendo feita avaliações no tocante de comprimento da radícula e do hipocótilo, assim como da altura da plântula. Os dados obtidos no presente estudo permitem concluir que: os extratos obtidos de plantas de T. cinerea exercem efeito negativo na germinação das plântulas de alface. A altura das plântulas de alface é afetada pelo uso do extrato de folhas, caule e parte aérea + raízes de T. cinerea. Há necessidade, urgente, de esforços no sentido de se determinar os constituintes existentes nas diversas partes das plantas de $T$. cinerea.

Palavras-chave: alelopatia, planta invasora, germinação

\section{Recebido para publicação em 12/04/2016. Aprovado em 24/05/2016.}

1 - Médica Veterinária, Mestranda do Programa de Pós-Graduação em Medicina Veterinária da UFCG/Patos-PB. anayasha@hotmail.com 2 - Eng ${ }^{\circ}$ Agrônomo, Professor titular da Unidade Acadêmica de Engenharia Florestal da UFCG/Patos-PB. jacob_souto@uol.com.br

3 - Eng ${ }^{\circ}$ Florestal, Mestrando do Programa de Pós-Graduação em Ciências Florestais da UFCG/Patos-PB. cesarhenrique27@yahoo.com.br 4 - Enga Florestal, Doutoranda pelo Programa de Pós-Graduação em Ciências Florestais da UFRPE/Recife-PE. lyanne.florestal@hotmail.com 5 - Eng ${ }^{\circ}$ Florestal, Doutorando pelo Programa de Pós-Graduação em Ciências Florestais da UFRPE/Recife-PE. tiberiopcz@gmail.com 


\section{INTRODUCTION}

Allelopathy has been described as a process by which products of a secondary metabolism from a specific plant are spread, preventing germination and the development of other plants that are relatively close (OLIVEIRA, 2016). When those compounds present any inhibitory property, it may affect the germination of seeds of several species, and their sensitivity varies according to the concentration that is applied (SEVERINO, 2007).

Some studies have demonstrated the effects of aqueous extracts over the germination of seeds from different species (SOUZA-FILHO, 2009; ROSADO et al., 2009). In most of the species, the allelopathic effect is more evident when leaf extracts are used (SOUZA, et al., 2007).

The resistance or tolerance to secondary metabolites is a species-specific characteristic, with the presence of those more sensitive and referred as indicator plants of allelopathic activity, like Lactuca sativa L. (lettuce), Lycopersicon esculentum Miller (tomato) and Cucumis sativus L. (cucumber). In order to be indicated as a testing plant, the specie must present a fast and uniform germination and a degree of sensitivity that permit to express the results under low concentrations of allelopathic substances (SOUZA, et al., 2007).

Tephrosia cinerea, known as "blue false indigo", is not a very palatable plant, it is invasive, but, during the dry season, when there are not other fodder plants available, ovine animals eat them in large quantities, and the ingestion of the fresh plant, during 60-80 days, is toxic for the animal, causing a disease known as "water belly" due to the fact that the abdominal cavity presents great amounts of liquid, which leads to the increase of the abdominal volume. That liquid is also found in the thoracic and pericardial cavities. However, the most relevant injury can be seen in the animal's liver. Animals affected may present clinical signs weeks or months before they die, and there is not a treatment available. Although, if they are removed from the pastures, they may restore their health (SANTOS et al., 2007).

The recognition of flavonoids in different species of the genus Tephrosia and the antioxidizing activity attributed to the metabolites abovementioned appear as an incentive for the conduction of studies regarding the chemical constituents and the analysis of the antioxidizing activity, as well as the allelopathic power of $T$. cinerea, a species of great incidence in the Brazilian semiarid biome, not to mention the wide applicability in people's lives, yet lacking of validation studies (SANTOS et al., 2011).

There are few information on the allelopathic effects of $T$. cinerea components in cultivated species.

Faced with such fact, we aimed, in this paper, to study the potential allelopathic effects of aqueous extracts from the germination specie aforementioned in lettuce seed, in addition to the height of the radicle and the hypocotyl.

\section{MATERIALS AND METHODS}

The experiment was carried out in nylon screenhouse at the Laboratory of Plant Mineral Nutrition from the Federal University of Campina Grande (UFCG), Campus of Patos (State of Paraíba).

In order to conduct the experiments, samples of $T$. cinerea were collected from a nearby area to the unit of Patos/UFCG, from which the collected material was separated according to the following fractions: leaves, stem, roots and aerial part + roots (Figure 1).

The lettuce seeds (Lactuca sativa var. Crespa Cinderela), with a germination rate of $98 \%$, were purchased in a local commercial store.

To prepare the extracts, each fraction was mixed with deionized water to obtain an extract with $20 \%$ of concentration, from the homogenization in a blender for approximately 30 minutes. Afterwards, the material was filtered with a strainer and accommodated in dark glass bottles containing one litter, wrapped up in tin foil and kept under room temperature until it was ready to be used.

The experimental design that we employed was entirely of the casual type, comprising five treatments and four repetitions. The treatments consisted of: (1) no application of Tephrosia extract; (2) application of leaf extract of Tephrosia; (3) application of stem extract of Tephrosia plants; (4) application of root extract of Tephrosia plants; and (5) application of an extract obtained from the aerial parts + roots of Tephrosia plants.

We made use of aluminum trays (9.8" x 4.7" x 1.5"), having as a substrate autoclaved sand. In the seeding process, we placed 25 lettuce seeds per tray (experimental unit) and, subsequently, we 


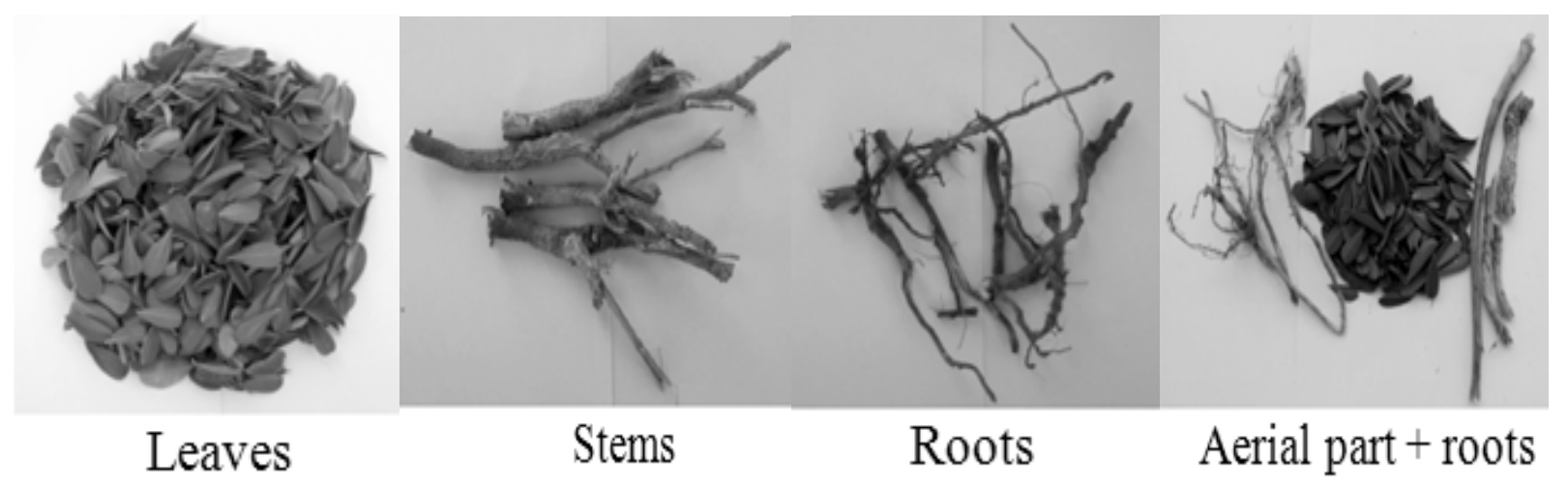

Figure 1. T. cinerea material separated in fractions for the preparation of the extracts.

applied the extracts referred to each treatment.

The germination started three days after the seedling, and, a week later, the experiment was discontinued. After the discontinuation of the experiment, the following procedures were carried out: measurement of the height of the radicle and hypocotyl, germination rate, speed index and average germination time.

The count of the number of germinated seeds was performed in a daily basis, being considered the germinated seed that presented a primary root with approximately 0.39 " of height. The seed count test was based on the principle that the samples which showed a higher rate of average seedlings are the most vigorous (BRASIL, 1992).

Regarding the speed of germination index, the evaluations of the lettuce seedlings were done in a daily basis, at the same time, starting from the day when the first average seedlings bloomed, having being evaluated until the seventh day after the seeding phase. The speed index of germination was calculated through daily data about the amount of average seedlings, making use of the formula proposed by Krzyzanowski et al. (1999).

$$
\mathrm{ISGI}=\frac{\mathrm{G} 1}{\mathrm{~N} 1}+\frac{\mathrm{G} 2}{\mathrm{~N} 2} \ldots+\frac{\mathrm{Gn}}{\mathrm{Nn}}
$$

where,

SGI = speed of germination index;

G1, G2, Gn = amount of average seedlings calculated in the first, second and last count; and $\mathrm{N} 1, \mathrm{~N} 2, \mathrm{Nn}=$ amount of days with which the seeding took place in the first, second and last count.
The average time of germination was obtained through daily counts of germinated seeds until the seventh day after sowing and calculated by the following formula proposed by Labouriau (1983), being the results expressed in days.

$\mathrm{AGT}=\Sigma(\mathrm{ni} . \mathrm{ti}) / \Sigma \mathrm{ni}$

where,

AGT $=$ Average germination time (days);

$\mathrm{ni}=$ Number of seeds germinated in each count interval between; and

$\mathrm{ti}=$ Time elapsed between the onset of germination and the ith counting.

Immediately after deactivation of the experiment, were collected lettuce seedlings of each replicate, separately and placed in petri dishes with water to remove the excess sand and following the measurement of the radicle was performed using a caliper digital. Concurrently, they evaluated the length of hypocotyl and the height of the seedling, also with the aid of a digital caliper.

Data were subjected to analysis of variance and means compared by Tukey test at $5 \%$ probability. We used the ASSISTAT program (version 7.0).

\section{RESULTS AND DISCUSSION}

Data relating to lettuce seed germination subjected to extracts from different parts of $T$. cinerea are shown in Table 1. Consider that the following data were transformed into square root of $\mathrm{x}$ plus 1 . 
Table 1. Effect of Tephrosia cinerea extract on germination (G), germination speed index (GSI) and mean germination time (MGT) of lettuce seeds

\begin{tabular}{cccc}
\hline Treatments & $\begin{array}{c}\mathrm{G} \\
(\%)\end{array}$ & $\begin{array}{c}\text { GSI } \\
(\%)\end{array}$ & $\begin{array}{c}\text { MGT } \\
\text { (days) }\end{array}$ \\
\hline Without Tephrosia extract & $6,920 \mathrm{a}^{*}$ & $2,572 \mathrm{a}$ & $2,507 \mathrm{c}$ \\
Leaf Extract & $1,000 \mathrm{~b}$ & $1,000 \mathrm{~b}$ & $2,830 \mathrm{a}$ \\
Stem Extract & $1,000 \mathrm{~b}$ & $1,000 \mathrm{~b}$ & $2,830 \mathrm{a}$ \\
Root Extract & $1,290 \mathrm{~b}$ & $1,300 \mathrm{~b}$ & $2,695 \mathrm{~b}$ \\
Aerial part + root extract & $1,000 \mathrm{~b}$ & $1.000 \mathrm{~b}$ & $2,830 \mathrm{a}$ \\
\hline lsd** & 1,452 & 0,381 & 0,111 \\
CV $(\%)$ & 29,65 & 12,69 & 1,87 \\
\hline
\end{tabular}

* Means followed by the same letter in the columns do not differ statistically from each other when compared by Tukey test (p $<$ $0,05) ; * *$ least significant difference.

This finding observed in Table 1 gives indication that Tephrosia plants have some/some component(s) which may (m) exercise allelopathic effect on lettuce. Therefore, further studies need to be performed in order to determine what those components contained in extracts from various parts of the plant that are inhibiting the growth of lettuce plants. This same observation applies to other plants.

Similar results to those observed in this study were found by Cantanhede Filho et al. (2013) to apply the extracts of $T$. cinerea sheets obtained with ethyl acetate and methanol showed high inhibitory potential for seed germination of two invasive species of grasslands, Mimosa pudica and Senna obtusifolia. According to the authors, the ethyl acetate extract showed inhibition percentage of $90.3 \%$ for species Mimosa pudica and $80.6 \%$ for Senna obtusifolia. But the methanol extract had inhibition percentage of $80.64 \%$ and $32.23 \%$ for Mimosa pudica to Senna obtusifolia, respectively. However, these authors also found that when it received the extract from Tephrosia leaves cinerea using hexane extract, this presented the inhibition percentage of $48.4 \%$ for Mimosa pudica and a stimulus of $3.3 \%$ for the species Senna obtusifolia.

When viewing the Table 2, it appears that the obtained extract of Tephrosia roots shows significant and positive effect on the growth of lettuce plants radicle. However, there was no difference in the treatment in which did not apply the Tephrosia extract. However, it is interesting to note that the extract obtained from the aerial parts as a whole or of its components in isolation, caused a reduction in the growth of the primary root of lettuce plants.

If this is so, mister becomes conducting research with extracts obtained from the aerial part of the plant Tephrosia in order to identify which components would be providing this deleterious effect on radicle, not just for lettuce but also to other plants.

Regarding the hypocotyl, it is observed that the various Tephrosia extracts applied at sowing did not produce significant effects on the hypocotyl length of lettuce $(p<0,05)$. The root system of plants is the most sensitive allelochemicals action because his stretching depends on cell divisions, which, if inhibited, compromise their normal development. Malformation in lettuce seedlings were also observed by Nery (2008) to study the allelopathic effect of turnip extract, which affected $87 \%$ of the analyzed plants with small-sized hypocotyl and oxidized and blackened roots.

\section{REVENG}


Table 2. Effects of Tephrosia cinerea extract application on root growth (RG), shoot height (SH) and growth of hypocotyl $(\mathrm{GH})$ of lettuce seedlings

\begin{tabular}{lccc}
\hline \multicolumn{1}{c}{ Treatments } & RG & SH & GH \\
\hline Without Tephrosia extract & -------- & cm \\
Leaf Extract & $0,775 \mathrm{ab}^{*}$ & $1,175 \mathrm{a}$ & $0,775 \mathrm{a}$ \\
Stem Extract & $0,700 \mathrm{~b}$ & $0,700 \mathrm{~b}$ & $0,700 \mathrm{a}$ \\
Root Extract & $0,700 \mathrm{~b}$ & $0,700 \mathrm{~b}$ & $0,700 \mathrm{a}$ \\
Aerial part + root extract & $1,125 \mathrm{a}$ & $1,150 \mathrm{a}$ & $1,175 \mathrm{a}$ \\
\hline lsd** & $0,700 \mathrm{~b}$ & $0,700 \mathrm{~b}$ & $0,700 \mathrm{a}$ \\
$\mathrm{CV}(\%)$ & 0,3624 & 0,3898 & 0,503 \\
\hline
\end{tabular}

* Means followed by the same letter in the columns do not differ statistically from each other when compared by Tukey test (p < $0.05)$;** least significant difference.

\section{CONCLUSION}

- $\quad$ The extracts of $T$. cinerea plants exert negative effect on germination of lettuce seedlings. Since the height of the lettuce seedlings was affect by the use of the leaf extract, stem and shoot + roots of $T$. cinerea. There is, urgent need, efforts in order to determine the existing constituents in different parts of plants $T$. cinerea.

\section{REFERENCES}

BRASIL, Ministério da Agricultura e Reforma Agrária. Regras para Análise de Sementes. Brasília: Biblioteca Nacional de Agricultura, 1992. 365p.

CANTANHEDE FILHO, A.J.; COSTA MORAES, R.P.; SANTOS, L.S. Atividade Alelopática de Extratos de Tephrosia cinerea. In: Congresso Brasileiro de Química, 53, 2003, Rio de Janeiro. Anais... Rio de janeiro: 2013. p.1-2.

KRZYZANOWSKI, F.C.; VIEIRA, R.D.; FRANÇA NETO, J.B.. Vigor de sementes: conceitos e testes. Londrina: ABRATES, 1999. $218 \mathrm{p}$.

LABOURIAU, L.G.A germinação das sementes. Washington: Secretaria Geral da Organização dos
Estados Americanos, 1983. 174p.

NERY, M.C. Germinação e potencial alelopático de Raphanus sativus L. var. oleiferus. 2008. 116 f. Tese (Doutorado em Fitotecnia) - Curso de PósGraduação em Fitotecnia, Universidade Federal de Lavras, Lavras, 2008.

OLIVEIRA, A.K.; COELHO, M.F.B.; TORRES, S.B.; DIÓGENES, F.E.P. Alelopatia de extratos de espécies da caatinga sobre sementes de meloeiro. Semina: Ciências Agrárias, Londrina, v.37, n.2, 2016.

ROSADO, L.D.S.; RODRIGUES, H.C.A.; PINTO, J.E.B.P.; CUSTÓDIO, T.N.; PINTO, L.B.B.; BERTOLUCCI, S.K.V. Alelopatia do extrato aquoso e do óleo essencial de folhas do manjericão "Maria Bonita" na germinação de alface, tomate e melissa. Revista Brasileira de Plantas Medicinais, Botucatu, v.11, n.4, 2009.

SAMPIETRO, D.A. Alelopatía: concepto, características, metodologia de estudio e importancia. Argentina: Universidad Nacional de Tucumán Ayacucho, 2007. Disponivel em: http:// www.biologia.edu.ar/plantas/alelopatia.htm. Acesso em: 20 nov. 2015.

SANTOS, J.C.A. Intoxicação em ovinos por Tephrosia cinerea. 2006. Dissertação (Programa 
de Pós-Graduação em Medicina Veterinária de Pequenos Ruminantes) - Universidade Federal de Campina Grande, Paraíba, 2006. (Dados ainda não publicados)

SANTOS, J.C.A; RIET-CORREA, F.; DANTAS, A.F.M.; BARROS, S.S.; MOLYNEUX, R.J.; MEDEIROS R.M.T.; SILVA, D.M.; OLIVEIRA O.F. Toxic hepatopathy in sheep associated with the ingestion of the legume Tephrosia cinerea. Journal of Veterinary Diagnostic Investigation, Columbia, v.19, n.6, 2007.

SANTOS, T.L.; AMARAL, F.M.M.; DUTRA, R.P.; FREITAS JUNIOR, L.M; CUNHA, M.S.; RIBEIRO, M.N.S. Estudo químico e avaliação da atividade antioxidante dos extratos de Tephrosia cinerea (L.) Pers. (Fabaceae). Revista de Ciências da Saúde, Paraíba, v.13, n.2, 2011.

SEVERINO, L.S.; LIMA, R.L.S.; ALBUQUERQUE, R.C.; BELTRÃO, E.M.
Alelopatia de plantas daninhas sobre a mamoneira - Embrapa Algodão. In: $2^{\circ}$ Congresso Brasileiro de Mamona, 2, 2006, Sergipe. Anais... Sergipe, 2007. p.1-4.

SOARES, G.L.G.; VIEIRA, T.R. Inibição da germinação e do crescimento radicular de alface (cv. "Grand rapids") por extratos aquosos de cinco espécies de Gleicheniaceae. Floresta e Ambiente, Rio de Janeiro, v.7, n.1, 2000.

SOUZA, C.S.M.; SILVA, W.L.P.; GUERRA, A.M.N.M.; CARDOSO, M.C.R.; TORRES, S.B. Alelopatia do extrato aquoso de folhas de aroeira na germinação de sementes de alface. Revista Verde, Paraíba, v.2, n.2, 2007.

SOUZA-FILHO, A.P.S.; SANTOS, R.A.; SANTOS, L.S.; GUILHON, G.M.P.; SANTOS, A.S.; ARRUDA, M.S.P.; MULLER, A.H.; ARRUDA, A.C. Potencial alelopático de Myrcia guianensis. Planta daninha, Viçosa, v.24 n.4, 2006. 